\title{
A NEW SALAMANDER FROM NORTH CAROLINA.
}

\author{
By Leonhard Stejneger, \\ Curator, Division of Reptiles and Batrachians.
}

A very strikingly colored salamander, plumbeous with brick-red legs, was recently presented to the Museum by Mr. C. S. Brimley, of Raleigh, North Carolina. It was collected by Mr. F. Sherman, jr., the entomologist, on August 24, 1904, near the extreme western corner of North Carolina, less than 20 miles from the border of Tennessee, between Andrews and Aquone, both of which localities are on streams draining into the Little Tennessee River. ${ }^{a}$

The tongue and other external characters, as well as the whole physiognomy of the animal, are so much like those of a Plethodon, and so different from Desmognathus, that I have not considered it necessary to mutilate the unique specimen in order to ascertain the character of the vertebræ.

\section{PLETHODON SHERMANI, new species.}

Diagnosis.-Parasphenoid patches of teeth separated; tongue large, posterior half free; fourteen costal folds; vomero-palatine teeth in two short, oblique series, not extending outward beyond the inner nares, widely separated behind and from the parasphenoid patches; tail very long, much longer than head and body, slender, and tapering to a fine point; color plumbeous, the legs brick-red in strong contrast.

Habitat.-Mountains of western North Carolina.

Type.-Cat. No. 36214, U.S.N.M.; Nantahala Mountain, between Andrews and Aquone; Mr. F. Sherman, jr., collector; August 24, 1904.

$a$ In a letter dated December 28, 1905, Professor Sherman, upon inquiry, gave the following more detailed information about the type locality: "I am morally certain that I took the specimen by side of rocky, shaded streamlet in the forest on the eastern (Aquone) side of the ridge [between Andrews and Aquone], more than half way to the summit, tho' I can now only dimly recall the exact place and circumstances. There are cool streamlets on that side of the ridge where I stopped to drink. That ridge must be about 4,500 feet at the summit, and is a branch of the Nantahala mountain or group of mountains.' 
Description of type.-Adu't: Vomero-palatine teeth (fig. 1) in two short, oblique, curved series, which do not extend outward beyond the choanæ, each series consisting of five to six rather large teeth; the distance between the series posteriorly equals about three-fourths of the length of the series; distance of vomero-palatine series from parasphenoid patches greater than length of series; parasphenoid teeth in two narrowly though distinctly separate patches, the teeth rather large, arranged in parallel, oblique rows, about five in each row; tongue very large, filling the entire floor of the mouth, thin, posterior half free, anterior portion narrowly attached along the median line; snout slightly projecting beyond lower jaw, rounded, truncate, or even slightly concave between the nostrils; distance between the latter equals the interorbital space and their distance from the eyes; a distinct groove from posterior margin of nostril to the edge of the lip, slightly oblique toward the front; a deep groove from posterior angle of eye along side of neck to the gular fold, another groove descending

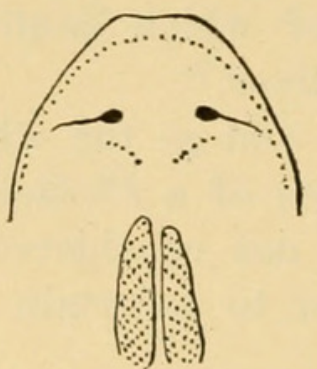

Fig. 1.

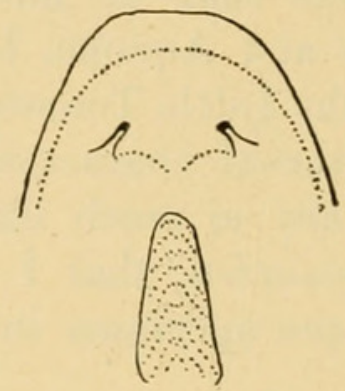

Fig. 2.

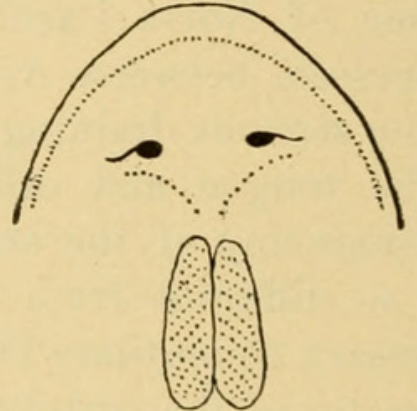

Fig. 3.

Fig. 1.-Dentition of Plethodon shermani. U.S. N. M. No. $36214.3 \times$ Nat. Size. Fig. 2.-Dentition of Plethodon eneus. U.S. N. M. No. $16660.3 \times$ Nat. size. Fig. 3.-Dentition of Plethodon Jordani. U.S. N. M. No. $35597.3 \times$ Nat. Size.

vertically from it behind the angle of mouth to the posterior end of the mandible; gular fold very deep, ascending on the sides of the neck; distance from tip of snout to gular fold contained about four times in distance to vent and about twice and a third times in distance between axilla and groin; limbs well developed, tips of fingers and toes nearly meeting when pressed along the sides of the body; digits not dilated at tips; fingers (fig. 4) well developed except inner, which is almost rudimentary, third much longer than second, which is longer than fourth; inner toe (fig. 5) very small, fourth longest, slightly longer than third, second and fifth subequal; tail slender, tapering to a point, subcylindric anteriorly, slightly compressed posteriorly, longer than head and body by the width of the head; fourteen strongly marked costal grooves, with one above and behind the insertion of the fore leg, and one above and in front of the hind leg, none of which descend to the lower surface. Color in life said to be "uniformly plumbeous with brick-red legs;" in alcohol, the color above and on the sides is bluish plumbeous, the whole surface under the magnifying glass showing a uniform dusting over of minute 
pale dots as in Plethodon glutinosus; underside pale gray with a glow of salmon color, strongest on throat; legs pale salmon color, the upper side of hands and feet finely dusted with dark grey, which color also forms a distinct bar across the elbows and the knees.

Dimensions.

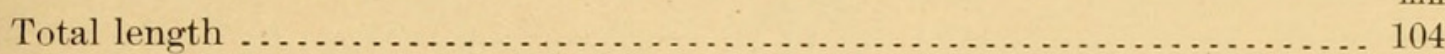

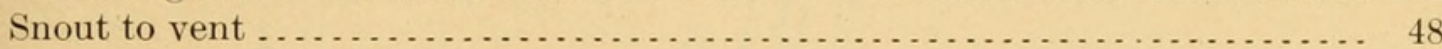

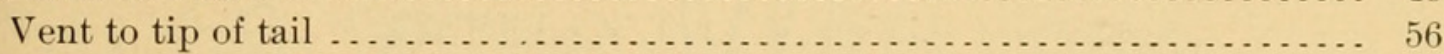

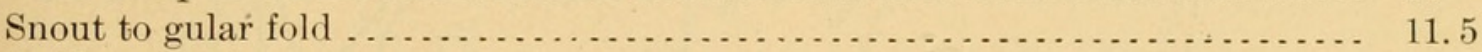

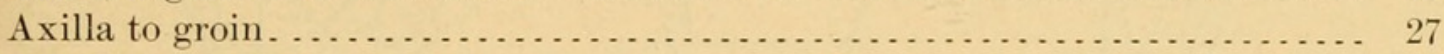

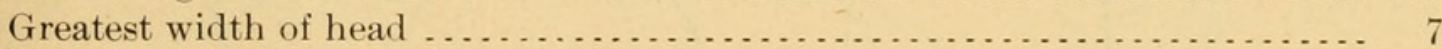

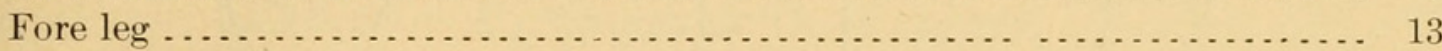

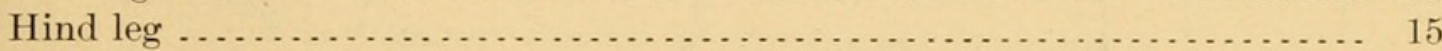

Remarks. - The direct relationship of this new salamander is not easy to trace. In the coloration of its legs it resembles very strongly the Californian Plethodon croceater, which also has a long tail, but here the similarity ends, for the shape of the head and the dentition as described by Cope are entirely different, besides many other discrepancies in relative length of toes, of limbs, and in number of costal folds, etc.

With our common eastern Plethodon glutinosus the new species has very little in common except the minute, pale, dust-like sprinkling of the dark skin. The proportions are entirely different, $P$. shemaani being much slenderer with a much longer and slenderer tail, while the dentition is still more at variance, $P$. glutinosus having the vomeropalatines extending beyond the choanæ and a single, undivided parasphenoid patch. The fifth toe is also relatively much longer than in P. glutinosus.

The proportions of $P$. xneus, on the other hand, are similar, except those of the head, which in this species is broad and squarish. The tail, also long and slender, is more cylindric though less tapering toward the tip. The hands and feet are also very different, being very broad and the digits distinctly widened at the tips (fig. 6). The coloration, moreover, is radically different and the dentition almost as much so, for while in $P$. shermani the teeth are large and few, the vomero-palatine series short, unusually far apart behind and placed far away from the distinctly divided parasphenoid patches, in $P$. æneus (fig. 2 ) the teeth are small and very numerous, the vomero-palatine series long, unusually close together behind and the parasphenoids on an undivided patch. Finally, while in the former the choanæ are large, in the latter they are uncommonly small.

Were it not that $P$. jordani (fig. 3) has the parasphenoid patches divided by a narrow groove we would scarcely have needed mention it in this connection, inasmuch as proportions and dentition otherwise is sufficiently different. It is a much stouter built animal and the teeth

Proc. N. M, vol. $\mathrm{xxx}-06-36$ 
much smaller, more closely approximated, and more numerous. Thus the vomero-palatine series are long and close together behind, the distance between them being less than one-third the length of the series, while externally they extend beyond the choanæ. Moreover, they contain ten to eleven teeth as against five to six in $P$. shermani.

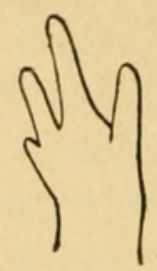

Fig. 4 .

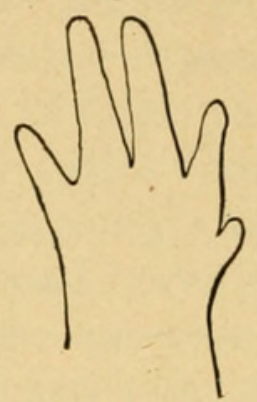

Fig. 5.

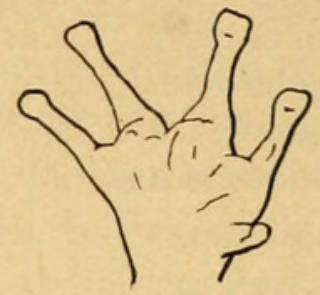

Fig. 6 .

Fig. 4.-UPPER SIDE OF Right FORE Foot of Plethodon Shermani. U.S. N.M. No. $36214.3 \times$ NAT. SIZE.

Fig. 5.-Underside of Right hind foot of Plethodon shermani. U.S.N.M. No. $36214.3 \times$ NAT. SIZE.

Fig. 6.-Underside of Right hind foot of Plethodon eneus. U.S.N. M. No. $16660.3 \times$ Nat. SIZE.

I have added camera lucida sketches of the dentition of the two lastmentioned species, which are still rare in collections, so that the differences from our new species can be seen at a glance.

Mr. F. Sherman, jr., has done considerable to increase our knowledge of the salamander fauna of North Carolina, and I therefore take great pleasure in naming this discovery of his after him. 


\section{$2 \mathrm{BHL}$ Biodiversity Heritage Library}

Stejneger, Leonhard. 1906. "A new salamander from North Carolina." Proceedings of the United States National Museum 30(1457), 559-562. https://doi.org/10.5479/si.00963801.30-1457.559.

View This Item Online: https://www.biodiversitylibrary.org/item/53722

DOI: https://doi.org/10.5479/si.00963801.30-1457.559

Permalink: https://www.biodiversitylibrary.org/partpdf/53132

\section{Holding Institution}

Smithsonian Libraries

\section{Sponsored by}

Smithsonian

\section{Copyright \& Reuse}

Copyright Status: Public domain. The BHL considers that this work is no longer under copyright protection.

This document was created from content at the Biodiversity Heritage Library, the world's largest open access digital library for biodiversity literature and archives. Visit BHL at https://www.biodiversitylibrary.org. 